\title{
Cardiovascular malformations in DiGeorge syndrome (congenital absence or hypoplasia of the thymus)
}

\author{
P MOERMAN, P GODDEERIS, J LAUWERIJNS, L G VAN DER HAUWAERT \\ From the Section of Paediatric Cardiology and the Department of Pathology, \\ University Hospital Gasthuisberg, Leuven, Belgium
}

SUMmaRY Partial or complete absence of the thymus (DiGeorge syndrome, III-IV pharyngeal pouch syndrome) is often associated with agenesis or hypoplasia of the parathyroid glands and, almost invariably, with cardiovascular malformations. The clinical and pathological findings in 10 cases proven at necropsy are presented. All patients presented with cardiac symptoms and signs in the first weeks of life and, with one exception, all died of a cardiac cause.

Major cardiovascular malformations were found in all 10 cases. Four had, in association with a ventricular septal defect of the infundibular type, an interrupted aortic arch, which was left-sided in two and right-sided in two other cases. Four patients had truncus arteriosus type $\mathrm{I}$, in two of them associated with a right-sided aortic arch. Two patients with tetralogy of Fallot had a right-sided aortic arch. Only two of the 10 had a normally developed left aortic arch. Aberrant subclavian arteries were found in five cases.

From our observations and a survey of the previously published patients it appears that 90 per cent of the necropsy-proven cases of DiGeorge syndrome have cardiovascular malformations and that 95 per cent of these malformations can be classified as aortic arch anomalies, truncus arteriosus, or tetralogy of Fallot.

Thymic aplasia or hypoplasia is often associated with complete or partial absence of the parathyroid glands and almost invariably with cardiovascular malformations. As both the thymus and parathyroid glands are derivatives of the same embryonic structures, this developmental anomaly has been called the III-IV pharyngeal pouch syndrome. ${ }^{2}$ DiGeorge $^{3}$ described the clinical syndrome characterised by neonatal hypocalcaemia and defective thymus-dependent cellular immunity in infancy in which the most common cause of death is severe cardiac malformation usually involving the aortic arch or conotruncus.

Our recent experience with 10 patients who died within the first year of life and came to necropsy indicates that this syndrome is not as rare as generally thought. This paper deals with the cardiovascular findings and reviews the published reports.

\section{Subjects}

In a consecutive series of 510 paediatric necropsies Received for publication 31 December 1979 performed at the University Hospital Gasthuisberg over a three-year period, the anatomy of the thymus was carefully examined as a routine. Ten patients with agenesis or hypoplasia of the thymus were found. Stress involution was differentiated from hypoplasia on the basis of the symmetrical aspect of the shrinkage and the persistence of the normal bilobed anatomy. In hypoplasia at least one lobe of the thymus is completely absent. Thymic aplasia was defined as the absence of thymic tissue in the upper mediastinum. In nine of the 10 patients the tissue of the anterosuperior mediastinum and neck, which had been removed en bloc, was serially sectioned at $5 \mu$ and every 10 th section was stained and histologically examined. All 10 patients had presented to the departments of paediatric cardiology or neonatology with cardiac symptoms and signs. Ventricular septal defects were classified after Goor and Lillehei ${ }^{4}$ and truncus arteriosus after Collett and Edwards. ${ }^{5}$ Two types of interrupted aortic $\operatorname{arch}^{6}$ were distinguished: interruption distal to the left subclavian artery (type A) and interruption distal to the left common carotid artery (type B). This terminology was also applied, 
mutatis mutandis, when a right-sided aortic arch was interrupted.

\section{Results}

\section{(1) CLINICAL OBSERVATIONS}

The relevant clinical data are summarised in Table 1. The sex predilection was predominantly male: seven male to three female. Maternal ages ranged between 22 and 39 years. Pregnancies lasted between 34 and 40 weeks and birthweight ranged between 1.1 and $3.8 \mathrm{~kg}$. In five cases pregnancy had been unremarkable. Pre-eclampsia had been noted in one case (case 2). In one mother (case 5) with a nodular goitre, thyroxin had been discontinued but thyroid function remained normal throughout pregnancy. Because of hydramnios a caesarean section was performed at 34 weeks of gestation. At birth the child had a goitre. Hydramnios was also a complication in two other pregnancies (cases 6 and 9). One mother (case 7 had had a febrile illness in the first trimester of pregnancy.

In all patients congestive heart failure or cyanosis were the presenting features which led to hospital admission. Only one infant (case 1) had severe hypocalcaemia and overt tetany. In one other patient (case 3) borderline hypocalcaemia $(8.1 \mathrm{mg} / 100 \mathrm{ml})$ did not produce neurological symptoms. The serum calcium level was normal in six of the eight cases in which it was determined. Bronchopneumonia was a complication in three patients (cases 2, 3, and 8) and oral moniliasis and gastroenteritis in one patient (case 8).

Cranofacial stigmata (Table 2) were noted in six patients. The most common were low-set ears, hypertelorism, and retrognathia (Fig. 1). The fairly specific "fish-mouth" appearance was observed in four cases. In one of them (case 3) this facial expression was enhanced by ankylosis of the mandibular joint.
Table 2 Craniofacial stigmata

\begin{tabular}{ll}
\hline Case no. & Craniofacial stigmata \\
\hline 1 & Low-set ears, retrognathia, high-arched palate \\
3 & $\begin{array}{l}\text { Hypertelorism, retrognathia, ankylosis of the mandibular } \\
\text { joint, fish-mouth }\end{array}$ \\
6 & $\begin{array}{l}\text { Hypertelorism, low-set ears, retrognathia } \\
\text { Low-set ears, short philtrum, retrognathia, and high- } \\
\text { arched palate, fish-mouth }\end{array}$ \\
8 & $\begin{array}{l}\text { Low-set ears, hypertelorism, retrognathia, fish-mouth } \\
\text { Slightly deformed ears, short philtrum, retrognathia, } \\
\text { fish-mouth }\end{array}$ \\
\hline
\end{tabular}

Death occurred within the first month of life in seven patients. Two patients died at 3 months. The longest survivor and only patient who was operated upon (case 7) died in a low cardiac output state three days after total correction of truncus arteriosus.

\section{(2) PATHOLOGICAL FINDINGS}

Cardiovascular anomalies (Table 3, Fig. 2)

All hearts were situated on the left side and presented with visceroatrial situs solitus and concordant atrioventricular connections.

Major aortic arch anomalies were encountered in four patients (Fig. 3). Two patients had an interrupted left aortic arch, type $A$ in one and type $B$ in the other. In two cases an interrupted right aortic arch type B was observed. All four patients had an infundibular ventricular septal defect. In one of them (case 2) a distinct shift of the crista supraventricularis to the left produced narrowing of the subaortic region above the ventricular septal defect (Fig. 4). In three patients (cases 4, 5, and 10) the aortic valve was bicuspid but not difinitely narrowed.

Six children had conotruncal anomalies. Truncus arteriosus type I was found in four children, in

Table 1 Clinical data in 10 patients with DiGeorge syndrome

\begin{tabular}{|c|c|c|c|c|c|c|c|}
\hline Case no. & Sex & $\begin{array}{l}\text { Maternal } \\
\text { age }(y)\end{array}$ & $\begin{array}{l}\text { Gestation } \\
(w k)\end{array}$ & $\begin{array}{l}\text { Birthweight } \\
(\mathrm{g})\end{array}$ & Hypocalcaemia & Age at death & Cause of death \\
\hline $\begin{array}{l}1 \\
2 \\
3 \\
4 \\
5 \\
6\end{array}$ & $\begin{array}{l}\mathbf{M} \\
\mathbf{M} \\
\mathbf{M} \\
\mathbf{F} \\
\mathbf{M} \\
\mathbf{M}\end{array}$ & $\begin{array}{l}22 \\
39 \\
24 \\
26 \\
29 \\
21\end{array}$ & $\begin{array}{l}36 \\
37 \\
40 \\
40 \\
34 \\
34\end{array}$ & $\begin{array}{l}2370 \\
2600 \\
3300 \\
2800 \\
2290 \\
1100\end{array}$ & $\begin{array}{l}\text { Severe } \\
\text { No } \\
\text { Slight } \\
\text { ND } \\
\text { No } \\
\text { ND }\end{array}$ & $\begin{array}{l}3 \text { months } \\
8 \text { days } \\
5 \text { days } \\
12 \text { days } \\
4 \text { hours } \\
2 \text { days }\end{array}$ & $\begin{array}{l}\text { Cardiac failure } \\
\text { Cardiac failure } \\
\text { Cardiac failure } \\
\text { Cardiac failure } \\
\text { Postnatal anoxaemia } \\
\text { Cardiac failure, } \\
\text { intravascular coagulation }\end{array}$ \\
\hline $\begin{array}{r}7 \\
8 \\
9 \\
10\end{array}$ & $\begin{array}{l}\mathbf{M} \\
\mathbf{F} \\
\mathbf{M} \\
\mathbf{F}\end{array}$ & $\begin{array}{l}28 \\
29 \\
28 \\
22\end{array}$ & $\begin{array}{l}38 \\
40 \\
36 \\
40\end{array}$ & $\begin{array}{l}2320 \\
3050 \\
2900 \\
3800\end{array}$ & $\begin{array}{l}\text { No } \\
\text { No } \\
\text { No } \\
\text { No }\end{array}$ & $\begin{array}{l}1 \text { year } \\
3 \text { months } \\
1 \text { month } \\
16 \text { days }\end{array}$ & $\begin{array}{l}\text { Postoperative death } \\
\text { Cardiac failure } \\
\text { Cardiac failure } \\
\text { Cardiac failure }\end{array}$ \\
\hline
\end{tabular}

ND, calcaemia not determined. 
two of them associated with a right aortic arch. The two patients with tetralogy of Fallot also had a right aortic arch. In one of them (case 6) agenesis of the pulmonary valve and aneurysmal dilatation of the main pulmonary artery were observed. At the site of the pulmonary valve only a fringe of nodular and dysplastic tissue was found. The ductus arteriosus was absent.

Anomalies of the subclavian arteries (Fig. 2) were common. Four patients had an aberrant left subclavian artery and one patient had an aberrant right subclavian artery. In one case with bilateral ductus arteriosus (case 10) the left subclavian artery was isolated from the aortic arch. It connected with the pulmonary artery via a left ductus arteriosus. The right ductus arteriosus supplied the descending aorta. Other cardiovascular findings were: bicuspid aortic valve (cases 4, 5, and 10), bicuspid pulmonary valve (case 4), and bilateral superior vena cava (case 3). Pulmonary venous connection was normal in all patients and in all the foramen ovale was patent, with an incompetent valve in three (cases 3, 4, and 6).

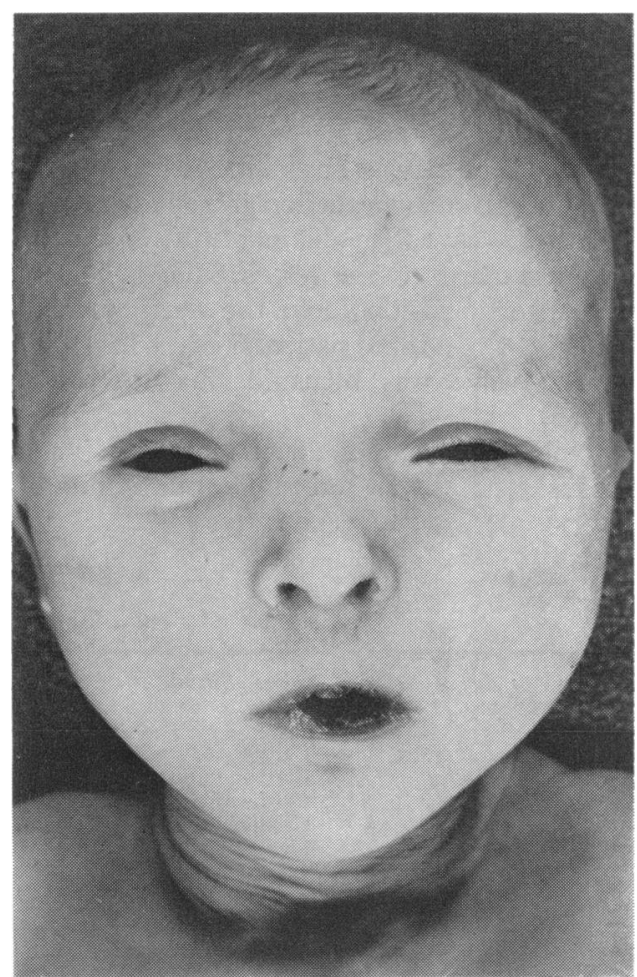

Fig. 1 Facies (case 8) characterised by low-set ears, hypertelorism, retrognathia, and fish-mouth appearance.
Thymus, lymph nodes, and spleen (Table 3)

In five patients (cases $1,2,7,8$, and 10) rudimentary fragments of the thymus could be identified macroscopically. They were derived from the right lobe and were usually ectopic. The left lobe was absent in all cases (Fig. 5). Serial histological examination of the cervical and mediastinal tissue showed small thymic remnants in three other patients (cases 4, 5, and 6). The histological structure of this thymic tissue was normal. Evidence of involution was slight to moderate. No thymic tissue could be found in the remaining two patients (cases 3 and 9).

Compared with the histological structure of the lymph nodes in children of the same age group, the lymph nodes in these 10 patients showed hypocellularity of the paracortical area. The degree of lymphoid depletion of the thymus-dependent zones, however, was variable, even in the same patient. The cortical zone of the lymph nodes was normal with primary and sometimes secondary follicles (cases 1 and 7).

Hypoplasia of the spleen was most striking in case 6 , a dysmature infant. The spleen was also abnormally small in the patients with no thymus (cases 3 and 9). In all patients a pronounced hypocellularity of the periarteriolar lymphocytic
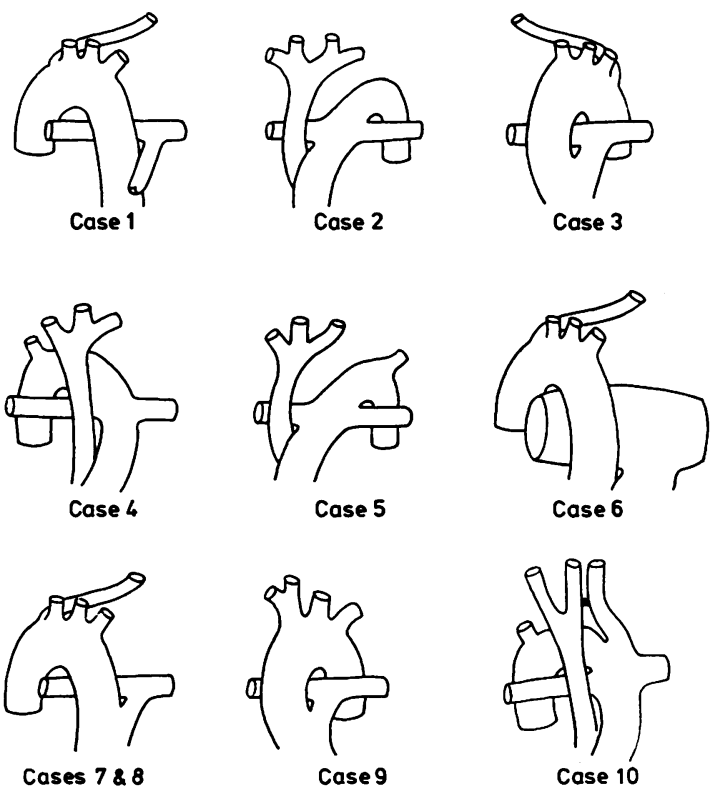

Fig. 2 Schematic representation of the great arteries arising from the heart in 10 patients with DiGeorge syndrome. 
Table 3 Pathological findings

\begin{tabular}{|c|c|c|c|c|}
\hline Case no. & Thymus* & Parathyroids & Spleen * & Cardiovascular system \\
\hline $\begin{array}{l}1 \\
2 \\
3\end{array}$ & $\begin{array}{l}1.0 \mathrm{~g} \text {, absence of left lobe } \\
2 \cdot 2 \mathrm{~g} \text {, absence of left lobe } \\
\text { Absent }\end{array}$ & $\begin{array}{l}\text { Absent } \\
3 \text { normal glands } \\
\text { Absent }\end{array}$ & $\begin{array}{r}15 \cdot 3 \mathrm{~g} \\
8 \cdot 3 \mathrm{~g} \\
3.8 \mathrm{~g}\end{array}$ & $\begin{array}{l}\text { Extreme TF, } R \text { aortic arch, aberrant } L \text { subclavian artery } \\
\text { Int } L \text { aortic arch type A, inf VSD, } L \text { shift of CSV } \\
\text { Truncus type I, inf VSD, aberrant } R \text { subclavian artery, } \\
\text { absent DA, bilateral SVC }\end{array}$ \\
\hline 4 & $\begin{array}{l}\text { Small nodule }(0.7 \mathrm{~cm} \\
\text { diameter) in } R \text { upper } \\
\text { mediastinum }\end{array}$ & Not examined & $11 \cdot 2 \mathrm{~g}$ & Int $R$ aortic arch type $B$, inf VSD, bicuspid aortic valve \\
\hline 5 & $\begin{array}{l}\text { Small nodule }(0.6 \times \\
0.3 \times 0.3 \mathrm{~cm}) \text { deep in } R \\
\text { mediastinum }\end{array}$ & Absent & $7.9 \mathrm{~g}$ & $\begin{array}{l}\text { Int } L \text { aortic arch type } B \text {, inf VSD, bicuspid aortic and pulmonary } \\
\text { valve }\end{array}$ \\
\hline 6 & $\begin{array}{l}\text { Small nodule ( } 0.5 \mathrm{~cm} \\
\text { diameter) in } R \text { upper } \\
\text { mediastinum }\end{array}$ & $\begin{array}{l}1 \text { hypoplastic } \\
\text { gland }\end{array}$ & $2.5 \mathrm{~g}$ & $\begin{array}{l}\text { TF, absent pulmonary valve, } R \text { aortic arch, aberrant } L \text { subclavian } \\
\text { artery, absent DA }\end{array}$ \\
\hline 7 & $\begin{array}{l}0.5 \mathrm{~g} \text {, small nodule } \\
\text { under } \mathrm{R} \text { thyroid lobe }\end{array}$ & 1 normal gland & $23.0 \mathrm{~g}$ & $\begin{array}{l}\text { Truncus type I, inf VSD, } R \text { aortic arch, aberrant } L \text { subclavian } \\
\text { artery, absent DA }\end{array}$ \\
\hline 8 & $0.8 \mathrm{~g}$, absence of left lobe & 2 normal glands & $5.6 \mathrm{~g}$ & $\begin{array}{l}\text { Truncus type I, inf VSD, } \mathrm{R} \text { aortic arch, aberrant } \mathrm{L} \text { subclavian } \\
\text { artery, absent DA }\end{array}$ \\
\hline $\begin{array}{r}9 \\
10\end{array}$ & $\begin{array}{l}\text { Absent } \\
0.4 \mathrm{~g} \text {, small nodule along } \\
\mathrm{R} \text { carotid artery }\end{array}$ & $\begin{array}{l}2 \text { normal glands } \\
2 \text { normal glands }\end{array}$ & $\begin{array}{l}6.2 \mathrm{~g} \\
5.9 \mathrm{~g}\end{array}$ & $\begin{array}{l}\text { Truncus type I, inf VSD, absent DA } \\
\text { Int } R \text { aortic arch type } B \text {, inf VSD, bicuspid aortic valve, } \\
\text { bilateral } D A\end{array}$ \\
\hline
\end{tabular}

\section{*weight in grams.}

CSV, crista supraventricularis; DA, ductus arteriosus; inf, infundibular; int, interrupted; L, left; R right; SVC, superior vena cava; TF, tetralogy of Fallot; truncus, truncus arteriosus; VSD, ventricular septal defect.

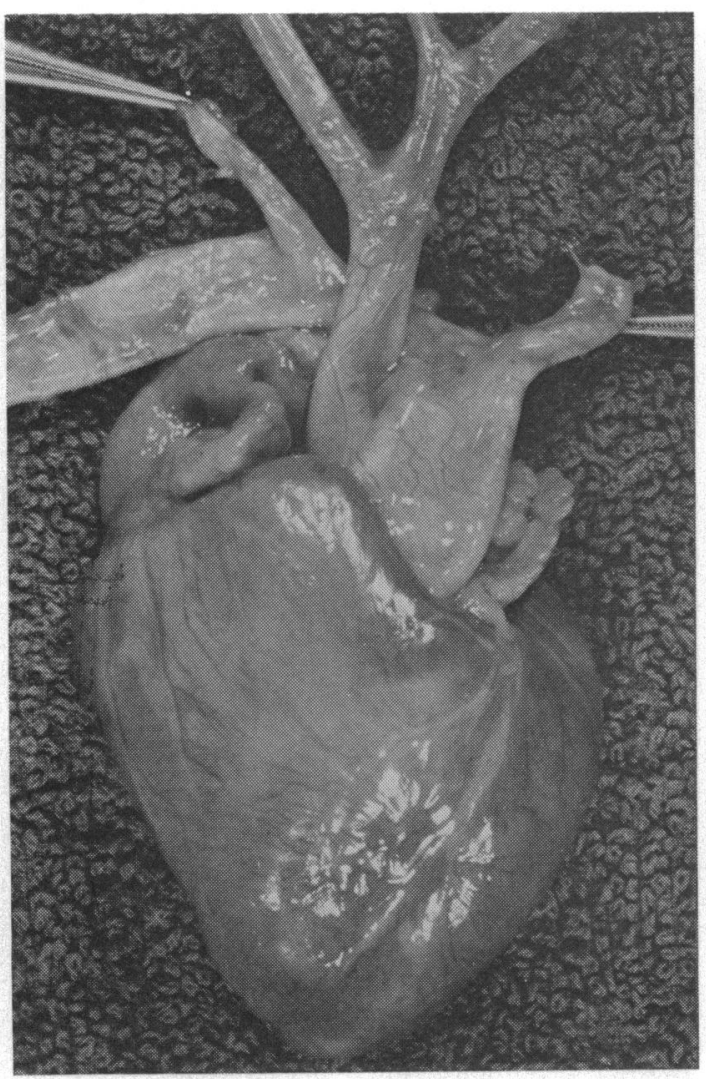

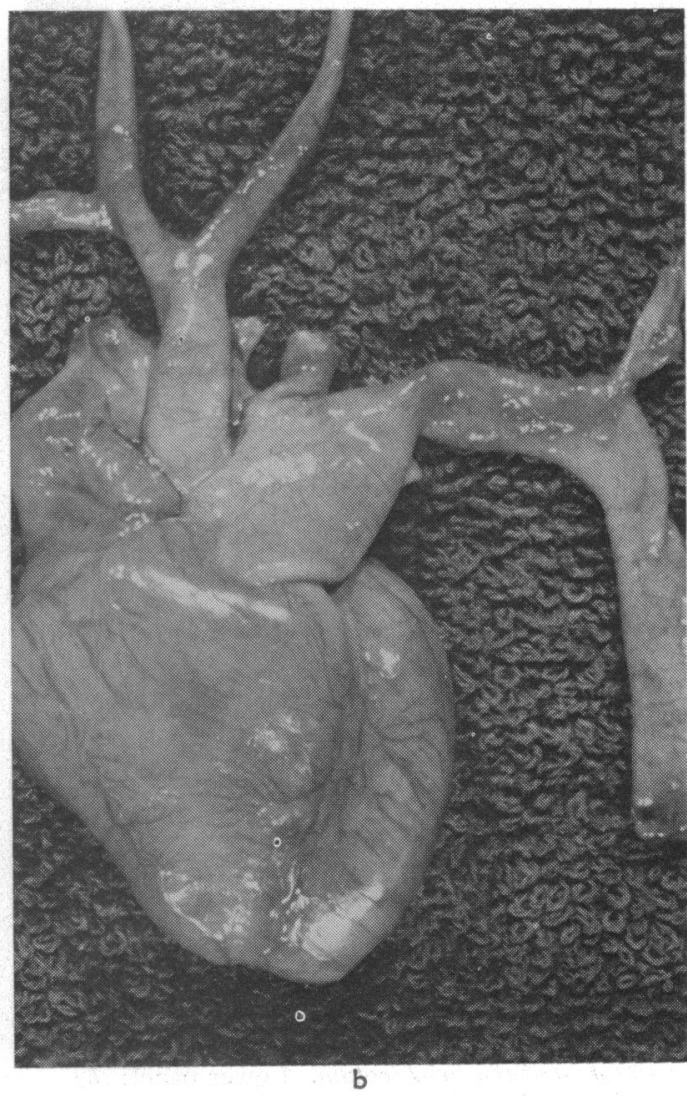

b

Fig. 3 Interrupted aortic arch. (a) Type B interruption, between the right common carotid artery and the right subclavian artery, in a patient with right aortic arch (case 4). A large ductus arteriosus connects the pulmonary artery with the descending aorta and the right subclavian artery. (b) Type B interruption, between the left common carotid artery and the left subclavian artery, in a patient with left aortic arch (case 5). 
sheets was observed. In one patient (case 7) germinal centres in the white pulp were noted.

\section{Thyroid and parathyroids}

No gross abnormalities of the thyroid glands were seen. In one patient (case 3) the isthmus was absent. In the patient with congenital goitre (case 5) histological examination showed empty follicles, devoid of colloid and bordered by highcylindrical cells. The histological structure of the thyroid gland was normal in the others. Even

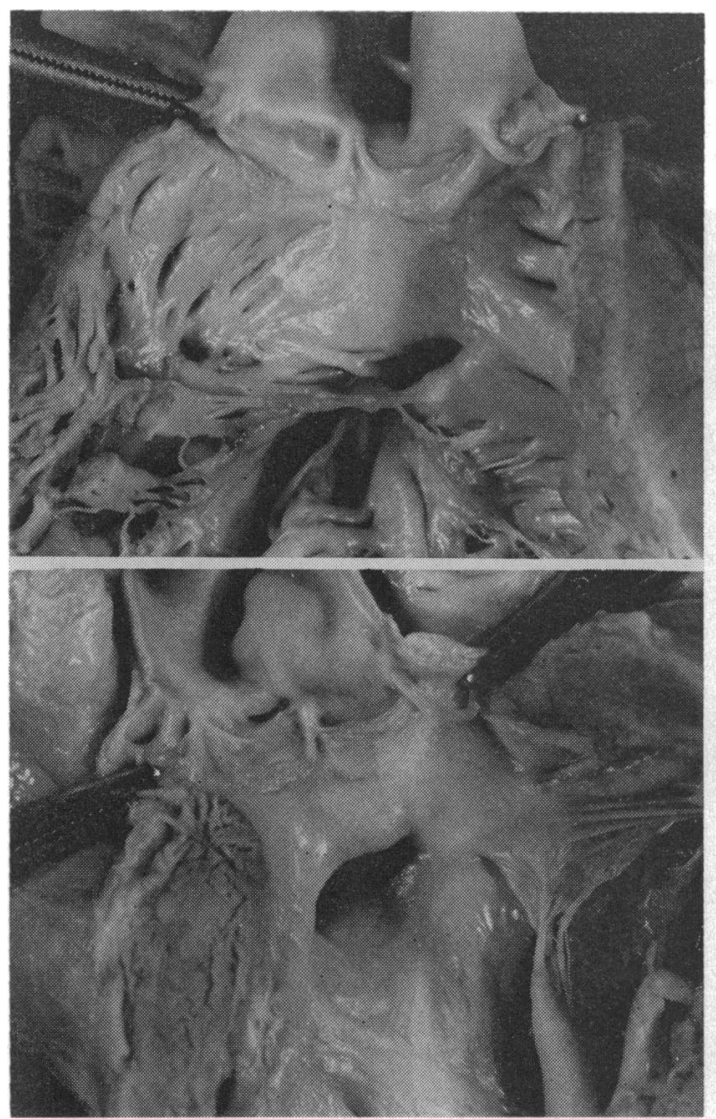

Fig. 4 Ventricular septal defect in a patient with interrupted left aortic arch (case 2). Upper panel: in the opened right ventricle an oval-shaped ventricular septal defect is seen in an unusual location between the conus septum and the sinus septum. Lower panel: the left ventricular view. A muscular band below the aortic valve produces narrowing of the left ventricular outflow tract above the ventricular septal defect. It is probably the result of a leftward shift of the crista supraventricularis (see text). after serial sectioning and histological examination of the anterior mediastinum and neck, which was done in nine of the 10 patients, no parathyroid tissue could be found in three cases (cases 1, 3, and 5). In one patient (case 6) one hypoplastic parathyroid gland was found at the upper pole of the right thyroid lobe. In the other patients, one (case 7), two (cases 8, 9, and 10) or three (case 2) normal parathyroids were found. When present these glands showed a normal histological structure.

\section{ADDITIONAL FINDINGS}

One patient (case 1) had hammer toes and bilateral clinodactyly of the 5 th finger. Microscopical examination of the right kidney in this patient showed small cartilaginous islands, with absence of cystic structures. The left umbilical artery was

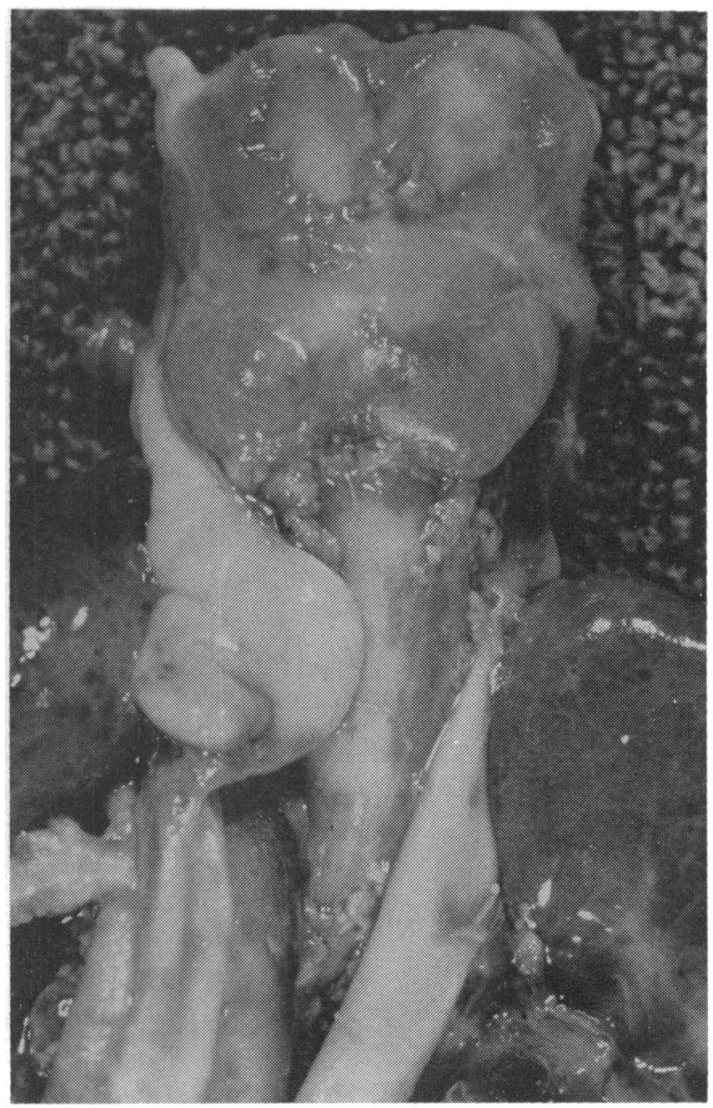

Fig. 5 Typical aspect of upper mediastinum at necropsy (case 7). The left lobe of the thymus is absent. A small shrimp-shaped nodule of thymic tissue is seen below the right thyroid lobe. 
absent in one patient (case 5). An abnormal lobulation of the right lung was found in seven patients: in three patients only two lobes were present, whereas in the remaining four patients the upper and median lobes were incompletely separated.

\section{Discussion}

Congenital absence of the thymus and parathyroid glands has, for many years, been known to be a cause of neonatal hypocalcaemia and tetany. ${ }^{7}$ The association with cardiovascular malformations was first noted by Lobdell $^{8}$ and by Farber and Vawter. ${ }^{9}$ DiGeorge $^{3}$ described the clinical spectrum and emphasised the deficit of thymic-dependent immunity. Though the anomaly has been reported as the III-IV pharyngeal pouch syndrome, ${ }^{110}$ the term DiGeorge syndrome is now widely used. A critical review of the terminology and a classification have been presented by Lischner. ${ }^{11}$

Approximately 50 cases of the DiGeorge syndrome have been reported. The largest series ${ }^{1}$ comprises 10 cases but only three with pathological proof. A detailed description of the clinical and necropsy findings in six patients has been presented by Robinson ${ }^{2}$ who also reviewed the 26 cases reported before his study. To this number should be added two patients reported by Rose et al., ${ }^{12}$ four cases reported by Griscelli and Diebold, ${ }^{13}$ two cases described by Shepard et al.,14 and three described by Cintado Bueno et al. ${ }^{15}$

In view of the rarity of this syndrome we were surprised to find 10 patients coming to necropsy within a period of three years. This may partly be explained by the fact that the pathologist, alerted by the first case, paid particular attention to the development of the thymus and parathyroid glands in paediatric necropsies, particularly in patients who had congenital heart disease.

All patients presented with cardiac symptoms or signs in the first months of life and, with one exception, all died from a cardiac cause. Only one infant had overt tetany, one had borderline asymptomatic hypocalcaemia, whereas six of the eight patients in whom it was determined had normal serum calcium levels. Our findings are therefore at variance with most previous reports in which tetany or hypocalcaemia were often the major disturbance. They confirm, however, the observations of Cameron ${ }^{16}$ who found no signs of hypoparathyroidism in a series of 10 cases. These discrepancies may be explained by the variable pathological composition of the syndrome. Careful macroscopical and serial microscopical examination of the neck and anterior mediastinum performed in nine of our 10 cases, disclosed that in five patients at least one normal parathyroid gland was present. In one other patient one hypoplastic gland was found. Because of the unusual sites of ectopic tissue it is impossible to be certain that the remaining three patients did indeed have "aplasia" of the parathyroid glands. Farber and Vawter ${ }^{9}$ found parathyroid tissue high in the submucosa of the posterior pharynx and mentioned that ectopic tissue might also be located along the neural structures of the neck. While it is true that profound hypocalcaemia should alert the clinician to the possibility of DiGeorge syndrome, our experience indicates that this sign may be completely lacking.

Defective cell-mediated immunity did not lead to serious clinical complications in the present series. However, no specific studies of immune function were performed, which might have disclosed an abnormally low percentage of thymusdependent lymphocytes ( $T$-lymphocytes) or depression in antibody response to specific immunisation. ${ }^{1117} \mathrm{~A}$ review of the previously reported children with an immunological deficit ${ }^{1}$ shows that they were older than our patients and that most of them had less severe heart disease. We presume therefore that the severity of the cardiac condition in our patients caused early death before immunological problems could arise. It should also be stressed that in many patients part of the thymus or ectopic thymic tissue may be found. ${ }^{2}$ In three of our patients a hypoplastic right lobe (weighing $0.8 \mathrm{~g}, 1.0 \mathrm{~g}$, and $2.25 \mathrm{~g}$ ) was present. In five other patients serial microscopical examination disclosed the presence of nodules of ectopic thymic tissue. Only two patients could, within the limits of careful post-mortem examination, be considered to be "athymic". The variability of the pathological findings and the corresponding degree of deficiency of the cellmediated immunity, led Lischner ${ }^{11}$ to propose a classification in which partial and complete forms of the DiGeorge syndrome are distinguished.

As commented on in previous studies ${ }^{12}$ some patients have a peculiar facies characterised by hypertelorism, low-set ears, a short philtrum, and retrognathia. A fish-mouth appearance was noted in four of our patients.

Various other anomalies have been reported in this syndrome, which, however, are neither constant nor characteristic: severe thyroid hypoplasia, ${ }^{2} 818$ oesophageal atresia, ${ }^{318}$ choanal atresia, ${ }^{18}$ hydronephrosis, ${ }^{1}$ and renal glomerular and tubular microcysts. ${ }^{2}$ It is noteworthy that seven of 10 patients in the present study had an abnormal lobulation of the right lung. This high incidence has not been reported before. 
Major cardiovascular malformations (Table 3) were observed in all 10 cases. Four patients had, in association with an infundibular septal defect, an interrupted aortic arch which was left-sided in two and right-sided in the other two. In one patient a leftward displacement of the crista supraventricularis produced narrowing of the subaortic region. The three other patients had a bicuspid aortic valve. Thus, in all four hearts a structure in the left ventricular outflow tract was found which, in fetal life, could have reduced forward aortic flow and impeded normal growth of the aortic arch. Identical observations in larger series of patients with interrupted aortic arch have been made by Van Praagh et al. ${ }^{19}$ and Moulaert. ${ }^{20}$ Four patients had truncus arteriosus type I and two had tetralogy of Fallot. Both these anomalies can be considered to be conotruncal malformations. Out of 10 patients only two (cases 3 and 9) had a normal left aortic arch. In two patients a left aortic arch was interrupted and in the remaining six the aortic arch was right-sided. Equally common were anomalies of the subclavian arteries, which were noted in six cases. Agenesis of the pulmonary valve and aneurysmal dilatation of the main pulmonary artery encountered in one of our patients with tetralogy of Fallot (case 6) have previously been described in two other patients with DiGeorge syndrome. ${ }^{12}$ The association has also been briefly mentioned by Cameron. ${ }^{16}$

Compiling the 26 cases reported or reviewed by Robinson, ${ }^{2}$ those reported by Rose et al., ${ }^{12}$ Shepard et al., ${ }^{14}$ Griscelli and Diebold, ${ }^{13}$ Cintado Bueno et al., 15 and the 10 patients of the present study, a total number of 52 well-documented cases are available for further analysis. Only seven out of 52 patients had normal cardiovascular findings. The cardiovascular malformations encountered in 45 patients are listed in Table 4. Right aortic arch, without associated anomalies, was observed in seven patients $(16 \%)$, double aortic arch in two $(0.44 \%)$, and interrupted aortic arch in eight cases $(18 \%)$. Twelve patients $(27 \%)$ had truncus arteriosus and $13(29 \%)$ had tetralogy of Fallot. A very high incidence (19 cases, $42 \%$ ) of right aortic arch was noted in the combined series: it occurred as an isolated anomaly in seven patients, in association with tetralogy of Fallot in seven, and with truncus arteriosus in three. In two patients in the present series (cases 4 and 10) a right-sided aortic arch was interrupted. There was no correlation between the type of the cardiovascular malformation and the degree of hypoplasia of the thymus and parathyroids.

The following conclusions can be reached: (1) cardiovascular malformations are found in approxi- mately 90 per cent of the necropsy-proven cases of DiGeorge syndrome, (2) the vast majority can be classified as aortic arch anomalies (right aortic arch, interrupted aortic arch, aberrant subclavian artery) and/or conotruncal anomalies (tetralogy of Fallot and truncus arteriosus). Together these rather uncommon types of malformation account for 95 per cent of all forms of congenital heart disease observed in this syndrome, (3) conversely, common types of congenital heart disease, such as isolated ventricular or atrial septal defect, coarctation of the aorta, and aortic stenosis have, to the best of our knowledge, not been reported.

The concurrence of malformations of the thymus and parathyroid glands can easily be explained by their embryogenesis, as the thymus originates from the third pharyngeal pouch and the parathyroid glands are derivatives of both the third and fourth pharyngeal pouches. The frequent association with relatively rare forms of congenital heart disease is intriguing and so far unexplained. Harvey et al. ${ }^{10}$ drew attention to the close proximity of the aortic arch and the third and fourth pharyngeal pouches during fetal life and postulated some sort of damage in this area at approximately four weeks' gestation. Robinson ${ }^{2}$ proposed an ingenious mechanism of pathogenesis in which the conotruncal anomaly would be the primary event,

Table 4 Cardiovascular malformations in 45 patients with DiGeorge syndrome

\begin{tabular}{|c|c|c|c|}
\hline Malformations & $\begin{array}{l}\text { Reported } \\
\text { cases* }\end{array}$ & $\begin{array}{l}\text { Present } \\
\text { study }\end{array}$ & $\begin{array}{l}\text { Combined } \\
\text { series }\end{array}$ \\
\hline $\mathbf{R}$ aortic arch & 7 & & 7 \\
\hline Double aortic arch & 2 & & 2 \\
\hline Interrupted aortic arch & & & 8 \\
\hline L aortic arch & 4 & 2 & 6 \\
\hline $\mathbf{R}$ aortic arch & & 2 & 2 \\
\hline Truncus arteriosus & & & 12 \\
\hline with L aortic arch & 7 & 2 & 9 \\
\hline with $\mathbf{R}$ aortic arch & 1 & 2 & 3 \\
\hline Tetralogy of Fallot & & & 13 \\
\hline with $\mathrm{L}$ aortic arch & 5 & & 5 \\
\hline $\begin{array}{l}\text { with } R \text { aortic arch } \\
\text { with } L \text { aortic arch and PV }\end{array}$ & 4 & 1 & 5 \\
\hline $\begin{array}{l}\text { agenesis } \\
\text { with } R \text { aortic arch and } P V\end{array}$ & 1 & & 1 \\
\hline agenesis & 1 & 1 & 2 \\
\hline $\begin{array}{l}\text { Transposition of great } \\
\text { grteries }\end{array}$ & & & \\
\hline $\begin{array}{l}\text { arteries } \\
\text { Pulmos }\end{array}$ & 1 & & 1 \\
\hline $\begin{array}{l}\text { Pulmonary stenosis } \\
\text { Persistent ductus arteriosus }\end{array}$ & 1 & & 1 \\
\hline (large) & 1 & & 1 \\
\hline Totals & 35 & 10 & 45 \\
\hline
\end{tabular}

* In this series the $\mathbf{2 6}$ cases with cardiovascular malformations reported or reviewed by Robinson ${ }^{2}$ were included. Also included were two cases reported by Rose et $a l$. , $^{12}$ one case reported by Shepard et al., 14 three cases reported by Griscelli and Diebold, ${ }^{13}$ and three cases reviewed by Cintado Bueno et al. ${ }^{15}$

$R$, right; $L$, left; $P V$, pulmonary valve. 
leading to altered perfusion of the left fourth aortic arch and its frequent deletion (interrupted aortic arch, right aortic arch). He further postulated the premature involution of the thyroidea ima artery which is the main embryonic blood supply of the third and fourth pharyngeal pouches. This hypothesis, however, has not been corroborated by pathological or embryological findings.

The DiGeorge syndrome does not seem to be genetically determined. A familial incidence has been reported rarely. ${ }^{14}{ }^{21}$ Males are more frequently affected than females with a sex ratio of approximately $2: 1$. No teratogenic agent has been incriminated so far.

We wish to thank Dr Richard Van Praagh and Dr André Moulaert for their criticism and valuable advice.

\section{References}

1 Freedom RM, Rosen FS, Nadas AS. Congenital cardiovascular disease and anomalies of the third and fourth pharyngeal pouch. Circulation 1972 ; 46: 16572.

2 Robinson HB Jr. DiGeorge's or the III-IV pharyngeal pouch syndrome. Pathology and a theory of pathogenesis. Perspect Pediatr Pathol 1975; 2: 173206.

3 DiGeorge AM. Discussions on a new concept of the cellular basis of immunity. $\mathcal{F}$ Pediatr 1965; 67: 907-8.

4 Goor D, Lillehei CW. Congenital malformations of the heart. New York: Grune \& Stratton, 1975.

5 Collett RW, Edwards JE. Persistent truncus arteriosus: a classification according to anatomic types. Surg Clin North Am 1949; 29: 1245-70.

6 Celoria G, Patton R. Congenital absence of the aortic arch. Am Heart $\mathcal{f} 1959$; 58: 407-13.

7 Rössle R. Ueber gleichzeitige Missbildungen der branchiogenen Organe und über angeborenen Mangel der Epithelkörperchen. Virchows Arch Pathol Anat 1932; 283: 41-57.

8 Lobdell DH. Congenital absence of the parathyroid glands. Arch Pathol 1959; 67: 412-5.

9 Farber S, Vawter G, eds. Clinical pathological conference, Children's Medical Center, Boston, Mass. F Pediatr 1960; 56: 690-7.

10 Harvey JC, Duncan WT, Elders MJ, Hughes ER. Third and fourth pharyngeal pouch syndrome, associated vascular anomalies and hypocalcemic seizures. Clin Pediatr 1970; 9: 496-9.

11 Lischner H. DiGeorge syndrome(s). I Pediatr 1972; 81: $1042-4$.

12 Rose JS, Levin DC, Goldstein S, Laster W. Congenital absence of the pulmonary valve associated with congenital aplasia of the thymus (DiGeorge's syndrome). Am F Roentgenol 1974; 122: 97-102.

13 Griscelli C, Diebold N. Le syndrome de DiGeorge. A propos de quatre nouvelles observations. Fournées Parisiennes de Pédiatrie 1976; 171-86.

14 Shepard MK, Linman SK, Cavazos A. Familial thymic aplasia with intrauterine growth retardation and fetal death: a new syndrome or a variant of DiGeorge syndrome. Birth Defects 1976; 12: 123-5.

15 Cintado Bueno C, Ariza Almeida S, Castillo Camacho JA, Atienza Contreras A, Toro Ortega J. Sindrome de DiGiorge. Estudo cardiologico en tres casos. An Esp Pediatr 1977; 10: 532-42.

16 Cameron A. Malformations of the thymus and cardiovascular system (abstract). Arch Dis Child 1965; 40: 334.

17 Gatti RA, Gershanik JJ, Levkoff AH, Wertelecki W, Good RA. DiGeorge syndrome associated with combined immonodeficiency. F Pediatr 1972; 81: 920-6.

18 Dische MR. Lymphoid tissue and associated congenital malformations in thymic agenesis. Arch Pathol 1968; 86: 312-6.

19 Van Praagh R, Bernhard W, Rosenthal A, Parisi L, Fyler DC. Interrupted aortic arch. Surgical treatment. Am $\mathcal{F}$ Cardiol 1971; 27: 200-11.

20 Moulaert A. Ventricular septal defects and anomalies of the aortic arch. Leiden: Thesis, University of Leiden, 1974.

21 Steele RW, Limas C, Thurman GB, Schuelein $M$, Bauer H, Bellanti JA. Familial thymic aplasia. Attempted reconstitution with fetal thymus in a millipore diffusion chamber. $N$ Engl f Med 1972; 287: 787-91.

Requests for reprints to Dr L G Van der Hauwaert, Section of Paediatric Cardiology, University Hospital Gasthuisberg, 3000 Leuven, Belgium. 